\title{
First report of beet western yellows virus infecting tomato in China
}

\author{
Yali Yan ${ }^{1} \cdot$ Jiakui Liu ${ }^{2} \cdot$ Xiaohui Sun ${ }^{1} \cdot$ Lianyi Zang ${ }^{1} \cdot$ Xianping Zhang ${ }^{1} \cdot$ Xiaoping Zhu $^{1}$ (D)
}

Received: 6 October 2018 / Accepted: 2 February 2019 / Published online: 5 August 2019

(C) Società Italiana di Patologia Vegetale (S.I.Pa.V.) 2019

Keywords Polerovirus $\cdot$ Beet western yellows virus $\cdot$ Tomato

Beet western yellows virus (BWYV, genus Polerovirus, family Luteoviridae) can infect a large number of crops and common weed species (Yuan et al. 2015). In June 2016, tomato samples with symptoms of chlorosis and bright yellowing leaves were collected in Jinzhong, Shanxi province, China. These symptoms are similar to those caused by infection of poleroviruses in tomato. To identify the pathogen, total RNA of 13 symptomatic samples from different tomato plants was extracted, and RTPCR was carried out using the general polerovirus primers Pol-G-F and Pol-G-R (Knierim et al. 2010), whereas samples from asymptomatic tomato plants were used as negative controls. Amplicons with expected size were obtained from four symptomatic samples, but not from the asymptomatic samples. The amplicons were sequenced, and their sequences were identical. One of the sequences was deposited in GenBank (MH645905), and the sequence showed 98\% nucleotide identity with a BWYV isolate from Leonurus sibiricus in Korea (KM076647). To further confirm the occurrence of BWYV in tomato, specific primers (CP-F:5'-ATGAATACGGTCGTGGGTAG-3'; CP-R: 5'CTATTTGGGATTGTGGAACT-3') which were expected to flank the whole coat protein gene were designed, and used for RT-PCR to test the same samples. The expected size (609 bp) of amplicons was obtained and sequenced (MH645906). The sequence shared 98\% identity with a pepper isolate (LC198684), and 99\% with KM076647. To

Xiaoping Zhu

zhuxp@sdau.edu.cn

1 Shandong Key Laboratory for Biology of Vegetable Diseases and Insect Pests, Plant Protection College of Shandong Agricultural University, Tai'an 271018, Shandong, China

2 Chiping Plant Protection Station, Chiping 252100, Shandong, China date, tomato as a host of BWYV has not previously been reported, therefore to confirm that BWYV can infect tomato plant, a BWYV infectious cDNA clone derived from a pepper isolate (MK307780) was used for inoculation by agroinfiltration; 17 of 40 tested plants displayed symptoms 15 days after inoculation, and the BWYV-positives were also confirmed by RT-PCR. BWYV was previously reported from field-grown pepper (Yuan et al. 2015), sugar beet and lettuce (Xiang et al. 2010) in China. To our knowledge, this is the first report of natural infection of tomato by BWYV.

Acknowledgements This research was supported by Shandong provincial natural science foundation (ZR2017MC061) and The Provincial Key Research and Development Program of Shandong (2017CXGC0207).

Publisher's note Springer Nature remains neutral with regard to jurisdictional claims in published maps and institutional affiliations.

\section{References}

Knierim D, Deng TC, Tsai WS, Green SK, Kenyon L (2010) Molecular identification of three distinct Polerovirus species and a recombinant Cucurbit aphid-borne yellows virus strain infecting cucurbit crops in Taiwan. Plant Pathol 59:991-1002

Xiang HY, Shang QX, Han CG, Li DW, Yu JL (2010) First identification of Beet western yellows virus on sugarbeet and lettuce in China. Plant Pathol 57:390

Yuan W, Yong RJ, Zuo LY, Du KT, Zhou T (2015) First report of Beet western yellows virus on pepper in China. J Plant Pathol 97:400 